\title{
Investigation on the Ecological Risk of Water Environment in the Main Stream Region of the Second Songhua River, China
}

\author{
Ding Wen-tao \\ Yingkou Environmental Assessment Co., Ltd \\ Yingkou, Liaoning, China
}

Jin Ke-xin

\author{
School of Environmental Science \\ Northeast Normal University \\ Changchun, Jilin, China
}

\author{
Sun Shi-jun ${ }^{*}$ \\ School of Environmental Science \\ Northeast Normal University \\ Changchun, Jilin, China \\ (* Corresponding Author, sunsj763@nenu.edu.cn)
}

\begin{abstract}
Based on the analysis of the potential ecological risk posed by the development of industrial cities along the Second Songhua River, according to the calculated ecological risk relative values and the development in different directions, the risk control measures aimed at different cities were put forward respectively. This study is a supplement of the domestic regional ecological risk research, and has a practical significance for the research of pollution control in the Songhua River. The result shows that the potential ecological risk in Jilin section, the greatest contribution to the potential risk is the toxic organic pollutants and heavy metals in sediments; the potential ecological risk in Songyuan section is slightly higher than that in front of the Fengman dam, the greatest contribution to the potential risk in Songyuan section is water pollution.
\end{abstract}

Keywords: the Second Songhua River; regional ecological risk; analytic hierarchy process; risk measures; pollution control

\section{INTRODUCTION}

At home and abroad, there is a lot research about the ecological risk assessment of water environment aiming at individual influence elements, the object of study mainly focused on some kinds of heavy metals in sediments and suspended solids or organic pollutants (pops), however the research on the regional ecological risk of water environment are not enough [1]. In China, the research on this aspect starts late, the study areas are more concentrated in Delta Wetland, Dongting Lake and the Tarim River Basin, the purpose is to reveal the potential ecological risk of these areas, then to put forward some protection measures for the whole areas [2].

The Second Songhua River as a source of Songhua River in the south, the upstream and section of it mainly are protected area and reserve zone, basically without pollution sources, the river pollution sources are distributed in exploitation area of the hilly-gully and downstream section, mainly concentrated in Jilin City and Songyuan City [3].The development of oil-based industry in Jilin and Songyuan City causes the more wastewater discharged into the Second Songhua River which has an adverse effects for a long term. Therefore, the study of ecological water environment risk is very necessary for solving the potential risk problem in the Second Songhua River. This study focused on the analysis of the potential ecological risk of industrial city along the Second Songhua River to the regional water, though the horizontal comparison for the potential ecological risk of construction industrial city along the river to the regional water environment, the longitudinal comparison for different construction of the city area to the potential ecological risk of water environment, the corresponding mitigation measures based on the characteristics of risk value are put forward, compared with the traditional research methods, the research has more far-reaching practical significance and reference for regional water resources environmental protection.

\section{STUDY AREA}

The Second Songhua River originates in An'tu County, Fusong Country and Changbai Mountain $\left(41^{\circ} 44^{\prime} \mathrm{N}\right.$, $124^{\circ} 26^{\prime} \mathrm{E}$ ), the River Course crosses from southeast to northwest, goes through An'tu County, Fusong Country, Dunhua City, Huadian City, Jingyu County, Jiaohe City, Jilin city, YongJi County, Jiutai City, Shulan City, Dehui City, Yushu City, Songyuan City, Fuyu County, eventually reaches Sancha River meeting with Nenjiang River $\left(45^{\circ} 24^{\prime} \mathrm{N}, 128^{\circ} 50^{\prime} \mathrm{E}\right)$. The total length of the Second Songhua River is $825.8 \mathrm{~km}$, the basin area is $73749 \mathrm{~km}^{2}$, among them, the basin area of the Second Songhua River in Jilin Province is $73229 \mathrm{~km}^{2}$, accounting for $99.3 \%$ of the total area, $39.1 \%$ of the total area of Jilin Province. 
Jilin City $\left(42^{\circ} 31^{\prime} \mathrm{N}-44^{\circ} 40^{\prime} \mathrm{N}, 125^{\circ} 40^{\prime} \mathrm{E}-127^{\circ} 56^{\prime} \mathrm{E}\right)$ is located in the middle of Jilin Province. Jilin City is a heavy industry city, an important chemical industry base in China. At the same time, metallurgy, machinery, cement industry development are also formed a certain scale, automobile, papermaking, food processing, textile industry are also relatively developed [4]. The main river in this area is the Second Songhua River which plays an important role in industry, agriculture and people's life.

Songyuan City is located in the mid-west of Jilin Province which is between $123^{\circ} 6^{\prime}$ to $126^{\circ} 11^{\prime}$ in east longitude, $43^{\circ} 59^{\prime}$ in north longitude to $45^{\circ} 32^{\prime}$. The industrial economy in Songyuan City already takes shape.

\section{STUDY ELEMENTS}

\section{A. Study scope}

The front of Fengman dam was the contrast section in this study, the potential ecological risk in Jilin and Songjiang section was analyzed. The evaluation scope was from the front of Second Songhua River dam $\left(43^{\circ} 43.153^{\prime} \mathrm{N}, 126^{\circ} 41.457^{\prime} \mathrm{E}\right)$ to Sancha River $\left(45^{\circ}\right.$ $\left.25.658^{\prime} \mathrm{N}, 124^{\circ} 39.896^{\prime} \mathrm{E}\right)$. The evaluation scope position is shown in Fig. 1.

Figure 1. The position of evaluation range

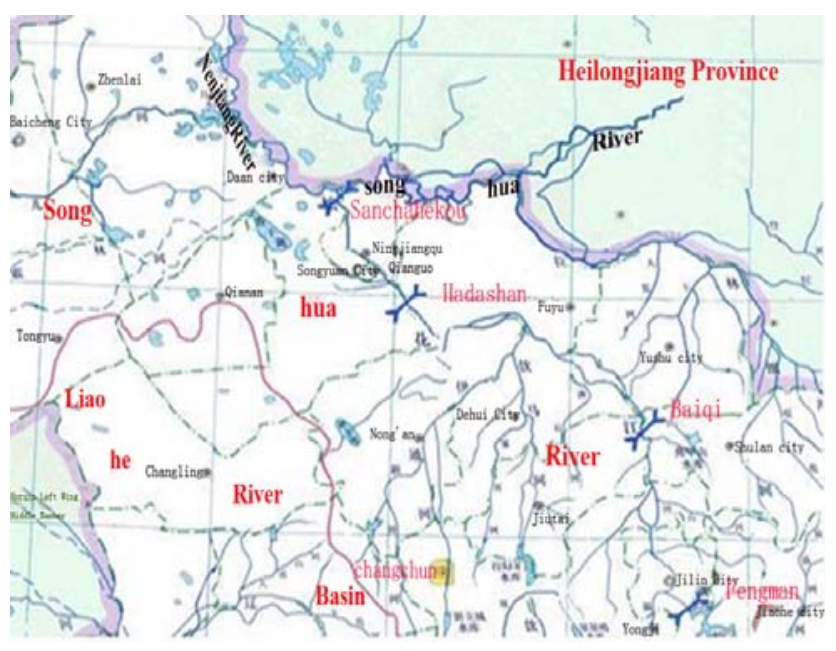

\section{B. Risk source analysis}

The waste water pollution source in Jilin City is mainly distributed in the both sides of Jilin section in the Second Songhua River, in 2008, most of the urban sewage, mixed wastewater was discharged after the treatment in sewage treatment plants. By the end of 2008 , the main pollution sources in Jilin City were discharged into 35 sewage outfalls [6]. The emission of COD into the river is $38268.36 \mathrm{t} / \mathrm{a}, 42.5 \%$ of that was industrial waste water, $56.8 \%$ of that was industrial and domestic mixing wastewater, domestic sewage account for $0.7 \%$. Therefore, industrial waste water is the main risk source. The major wastewater pollution sources in Jilin City are shown in Table 1.
TABLE I. THE STATISTICS OF WASTEWATER POLLUTION RESOURCE IN JILIN SECTION

\begin{tabular}{|c|c|c|}
\hline NUM & Sewage outfall & COD Emission (t/a) \\
\hline 1 & $\begin{array}{l}\text { Qianguo Branch of } \text { Buerdan } \\
\text { Company }\end{array}$ & 249.6 \\
\hline 2 & $\begin{array}{l}\text { Songyuan Branch of Buerdan } \\
\text { Company }\end{array}$ & 112.35 \\
\hline 3 & Xinyuan Chemical Company & 7.86 \\
\hline 4 & $\begin{array}{l}\text { Qianguo Petrochemical Branch of } \\
\text { China Petroleum }\end{array}$ & 248.4 \\
\hline 5 & $\begin{array}{l}\text { Huarun Cerestar Maize Industry Co. } \\
\text { Ltd. }\end{array}$ & 131.1 \\
\hline 6 & $\begin{array}{l}\text { Ji'an Biochemical Songyuan } \\
\text { Company }\end{array}$ & 744 \\
\hline 7 & $\begin{array}{l}\text { Songyuan Biochemical Technology } \\
\text { Co., Ltd. }\end{array}$ & 59.22 \\
\hline 8 & The Songyuan Brewery & 25.8 \\
\hline 9 & The comprehensive utilization of oil & \\
\hline 10 & Qianlian & \\
\hline 11 & Jiangnan Sewage Treatment Plant & 10074 \\
\hline 12 & Jiangbei Sewage Treatment Plant & \\
\hline Total & & 11652.33 \\
\hline
\end{tabular}

Jilin and Songyuan City are the major industrial city along the Second Songhua River, both of them dominated by petrochemical and food processing. Overall, the industrial wastewater is the main risk source for the water environment in the Second Songhua River. The major wastewater pollution sources in Songyuan City are shown in Table 2.

Figure 2. The water quality in each section of the Songhua River

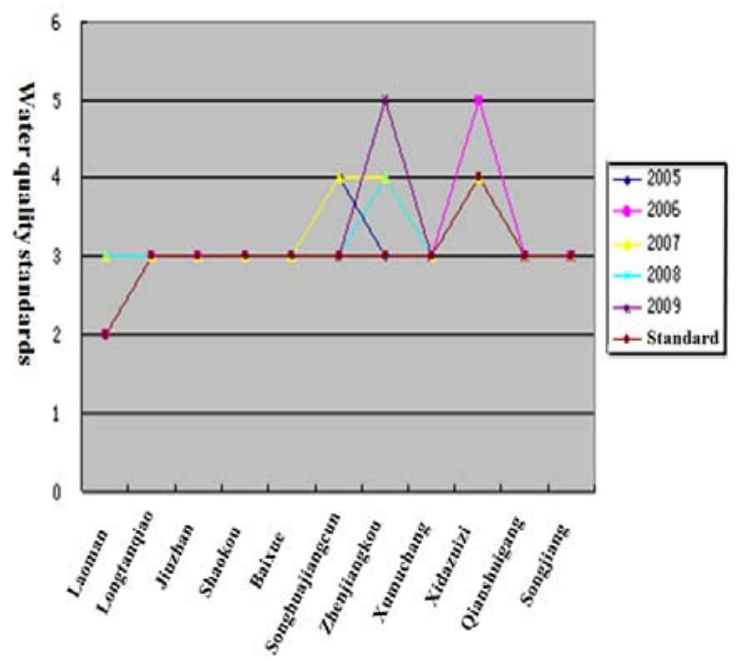

\section{Impact analysis}

1) Exposure analysis.

Exposure analysis is the study on the distribution, flow and contact exposure relationship of risk source in the evaluation region [8].

According to the survey, the water quality of each fracture surfaces in each year are shown in Fig. 2, the standard values in this figure is referenced by the surface water function division of Jilin Province [9]. 
As Fig. 2 shows, the water quality of the Second Songhua River was affected by the urban wastewater discharged from the city along the river, the water quality deterioration phenomenon occurred in some sections such as Fengman, Songhuajiang Village, Zhenjiang and west Dazuizi.

2) Risk analysis.

The pressure of industrial wastewater, sewage and other risk sources will reduce the quality and function of water in Second Songhua River, the release of risk sources will not only disrupt the aquatic ecosystem balance, also can seriously hinder the development of local economy. At present, the water quality in main part of the Songhua River is beyond the standard requirement.

TABLE II. THE STATISTICS OF WASTEWATER POLLUTION RESOURCE IN SONGYUAN CITY

\begin{tabular}{|c|c|c|}
\hline NUM & Sewage outfall & COD Emission (t/a) \\
\hline 1 & $\begin{array}{l}150 \mathrm{~m} \text {, downstream of Songjiang } \\
\text { Bridge }\end{array}$ & 1026.7 \\
\hline 2 & $\begin{array}{l}150 \mathrm{~m} \text {, downstream of Jilin Paper } \\
\text { Mill }\end{array}$ & 4292.4 \\
\hline 3 & $\begin{array}{l}150 \mathrm{~m} \text {, downstream of Jilin Paper } \\
\text { Mill }\end{array}$ & 3770.3 \\
\hline 4 & Jindong Cement plant and Tile Plant & 134.6 \\
\hline 5 & Jilin Carbon Plant & 1005.6 \\
\hline 6 & Ferroalloy Bridge & 3801.8 \\
\hline 7 & $\begin{array}{l}\text { Outfall of Jilin Wastewater Treatment } \\
\text { Plant }\end{array}$ & 6570 \\
\hline 8 & $\begin{array}{l}100 \mathrm{~m} \text {, downstream of Hada Power } \\
\text { Plant }\end{array}$ & 55.2 \\
\hline 9 & $\begin{array}{l}\text { Downstream of the overpass in } \\
\text { Jingkai Area }\end{array}$ & 52.6 \\
\hline 10 & Jilin Tuopai Company & 188 \\
\hline 11 & Jilin Fiber Plant & 130 \\
\hline 12 & Jilin Fiber Plant & 1604.46 \\
\hline 13 & Jilin Fuel ethanol & 144.1 \\
\hline 14 & Jiuxin Chemical Plant & 23.1 \\
\hline 15 & Jiuxin Chemical Plant & 25.4 \\
\hline 16 & Jiuxin Chemical Plant & 14.0 \\
\hline 17 & Number 10 in Shihuanan of Jilin City & 159.7 \\
\hline 18 & $\begin{array}{l}200 \mathrm{~m} \text {, downstream of Qianghua } \\
\text { Bridge }\end{array}$ & 30.7 \\
\hline 19 & $\begin{array}{l}20 \mathrm{~m} \text {, Jilin Thermal Power Plant } \\
\text { behind the old pump room }\end{array}$ & 64.6 \\
\hline 20 & $\begin{array}{l}25 \mathrm{~m} \text {, Jilin Thermal Power Plant } \\
\text { behind the old pump room }\end{array}$ & 39.8 \\
\hline 21 & Number 10 in Shihuadong of Jilin & 96.2 \\
\hline 22 & $\begin{array}{l}\text { Jilin Electromechanical vocational } \\
\text { school }\end{array}$ & 33.4 \\
\hline 23 & Tuchengzi Swimming pool & 103.3 \\
\hline 24 & $\begin{array}{l}15 \mathrm{~m} \text {, downstream of Tuchengzi } \\
\text { swimming pool }\end{array}$ & 360.0 \\
\hline 25 & The north of Paper Mill & 313.6 \\
\hline 26 & $30 \mathrm{~m}$, downstream of Halong Bridge & 17.1 \\
\hline 27 & Hanyang Street & 5.6 \\
\hline 28 & Across the Taihejin Ditch & 5.0 \\
\hline
\end{tabular}

\begin{tabular}{|l|l|c|}
\hline NUM & \multicolumn{1}{|c|}{ Sewage outfall } & COD Emission (t/a) \\
\hline 29 & Urban industrial sewage outfall & 145.4 \\
\hline 30 & Beida Ditch & 9382 \\
\hline 31 & Line 10 in Shihuaxi & 215.8 \\
\hline 32 & Line 10 in Acrylonitrile Plant & 47.5 \\
\hline 33 & $\begin{array}{l}\text { Sewage Treatment Plant in } \\
\text { Jilinshihua } \\
\text { Company upstream of Huarun Beer }\end{array}$ & 7321.8 \\
\hline 34 & $\begin{array}{l}\text { Upstream of Huarun Beer Company } \\
\text { outfall }\end{array}$ & 18.1 \\
\hline 35 & \multicolumn{1}{|c|}{38268.36} \\
\hline Total & \multicolumn{1}{|c|}{} \\
\hline
\end{tabular}

\section{ECOLOGICAL RISK RESEARCH OF WATER ENVIRONMENT}

\section{A. Biological risk index}

When calculating the biodiversity index, the weight of benthic animals is 0.5 , zooplankton is 0.3 , phytoplankton is 0.2 [12]. The model [13] is as follows:

$$
\mathrm{WH}=\mathrm{W}_{1} \mathrm{H}_{1}+\mathrm{W}_{2} \mathrm{H}_{2}+\mathrm{W}_{2} \mathrm{H}_{2}
$$

Where, BH-Integrated biodiversity index; $\mathrm{W}_{\mathrm{i}^{-}}$weight $\left(\mathrm{W}_{1}=0.2, \mathrm{~W}_{2}=0.2, \mathrm{~W}_{3}=0.5\right)$.

$\mathrm{H}_{\mathrm{i}}$ - biodiversity index $\left(\mathrm{H}_{1}\right.$ presents phytoplankton, $\mathrm{H}_{2}$ presents zooplankton, $\mathrm{H}_{3}$ presents benthic animals).

Biodiversity index adopted the Shannon- Weaver diversity index ( $\mathrm{H}$ value), expression is:

$$
\mathrm{H}=-\sum \mathrm{P}_{\mathrm{i}} \times \operatorname{LnP}_{\mathrm{i}}
$$

$\mathrm{P}_{\mathrm{i}}=\mathrm{n}_{\mathrm{i}} / \mathrm{N}$,

Where, $\mathrm{n}_{\mathrm{i}}$ - the individual number of biotic $\mathrm{I}$; $\mathrm{N}$ - the total number of individuals.

The sample data is obtained from Jilin section in April 2006 and Songyuan section in July 2010 by Northeast Normal University, then our study team do the sampling and analyze to the water in front of the Fengman dam, based on Hannon-Weaver diversity index and three sets of data mentioned before, the biological diversity index is calculated. (Table 3)

TABLE III. THE BIODIVERSITY INDEX

\begin{tabular}{|c|c|c|c|c|}
\hline \multirow{2}{*}{ River } & \multicolumn{4}{|c|}{ Biodiversity index } \\
\hline Jilin section & $\boldsymbol{H} \mathbf{1}$ & $\boldsymbol{H} \mathbf{2}$ & $\boldsymbol{H} \mathbf{3}$ & $\boldsymbol{B} \boldsymbol{H}$ \\
\hline & 1.26 & 1.20 & 1.10 & 1.162 \\
\hline $\begin{array}{c}\text { Songyuan } \\
\text { section }\end{array}$ & $\boldsymbol{H 1}$ & $\boldsymbol{H} \mathbf{2}$ & $\boldsymbol{H} \mathbf{3}$ & $\boldsymbol{B H}$ \\
\hline & 1.48 & 1.04 & 1.10 & 1.158 \\
\hline $\begin{array}{c}\text { The front of } \\
\text { Fengman dam }\end{array}$ & $\boldsymbol{H}_{\mathbf{1}}$ & $\boldsymbol{H}_{\mathbf{2}}$ & $\boldsymbol{H}_{3}$ & $\boldsymbol{B H}$ \\
\hline & 1.44 & 1.24 & 1.10 & 1.312 \\
\hline
\end{tabular}


After the calculation, we found the biological diversity index in the front of Fengman dam is higher than in Jilin and Songyuan section, just as expected results.

Comparing the biological diversity index in Jilin and Songjiang section, the index value in Jilin section is found a little higher, that is mainly because the large number of sandpits leads aquatic biology hard to live.

\section{B. Ecological vulnerability index}

\section{1) Heavy metal:}

The ecological vulnerability index (RI) of heavy metals and organic toxic in sediments is referenced by Haknson ecological risk index, the expression is as follows:

$$
\mathrm{RI}=\sum \mathrm{T}_{\mathrm{f}}^{\mathrm{i}} \times \mathrm{C}_{\mathrm{m}}{ }^{\mathrm{i}} / \mathrm{C}_{\mathrm{s}}^{\mathrm{i}}
$$

Where, $\mathrm{T}_{\mathrm{fi}}$ - the toxicity response factor of heavy metal I; $\mathrm{C}_{\mathrm{mi}}$ - the measured values of heavy metal I; $\mathrm{C}_{\mathrm{si}}$ the standard values of heavy metal i.

According to the references, the RI value of heavy metals and organic toxic in sediment is summarized. (Table 4)

The $\mathrm{E}_{\mathrm{i}}$ values of $\mathrm{Pb}$ in each sections change a lot, the value increases from Redrock Lake, reaching a maximum at 81.5 in Shaokou section, then shows a trend of reduction in downstream. It shows that the pollution sources of $\mathrm{Pb}$ mainly are industrial wastewater such as Jilin oil, chemical and other industrial wastewater.

TABLE IV. THE ECOLOGICALLY FRAGILE INDEX OF HEAVY METALS IN SEDIMENTS

\begin{tabular}{|c|c|c|c|c|}
\hline \multirow{2}{*}{ Subject } & \multicolumn{3}{|c|}{ Ei } & RI \\
\cline { 2 - 5 } & $\boldsymbol{A s}$ & $\boldsymbol{C r}$ & $\boldsymbol{P b}$ & \\
\hline Redrock Lake & 21.8 & 4.2 & 22.6 & 48.6 \\
\hline Hada Bay & 26.7 & 4.9 & 31.3 & 62.9 \\
\hline Shaokou & 27.5 & 2.8 & 69.8 & 100.1 \\
\hline $\begin{array}{c}\text { Average of Jilin } \\
\text { section }\end{array}$ & 27.1 & 3.9 & 50.55 & 81.5 \\
\hline $\begin{array}{c}\text { Hada Mountain } \\
\text { Songyuan City }\end{array}$ & 15.7 & 0.8 & 17.7 & 34.2 \\
\hline $\begin{array}{c}\text { Ganshuigang } \\
\begin{array}{c}\text { Average of } \\
\text { Songyuan } \\
\text { section }\end{array}\end{array}$ & 15.9 & 0.6 & 14.0 & 30.5 \\
\hline 2 Organic & 16.5 & 1.1 & 11.0 & 30.7 \\
\hline
\end{tabular}

2) Organic poison:

The quotient method was used to do potential ecological risk analysis of the organic poisons in river. The hazard quotient (Q) can be expressed by the quotient of exposure concentration (EEC) of organic poisons and ecological reference value (TRV) of the species. The expression is as follows:

\section{$\mathrm{Q}=\mathrm{EEC} / \mathrm{TOX}$}

Set the polycyclic aromatic hydrocarbons (PAHs) in the Second Songhua River as the representative of organic poisons, according to relevant data and literature, the ecological vulnerable index of organic poisons in

sediments was calculated by the quotient method. (see Table 5)

\section{3) Pollution risk index:}

The pollution risk index is the potential ecological risk, which can be used to characterize the aquatic ecosystem, and can be quantified by the pollution index and the specific formula, expression is:

$$
\mathrm{P}=\sum \mathrm{Pi}, \mathrm{P}_{\mathrm{j}}=\mathrm{C}_{\mathrm{j}} / \mathrm{C}_{\mathrm{s}}
$$

TABLE V. THE VALUE OF POLYCYCLIC AROMATIC IN SEDIMENT

\begin{tabular}{|c|c|c|c|}
\hline Subject & $\begin{array}{c}\text { EPAHs } \\
(\mathbf{n g} / \mathbf{g})\end{array}$ & $\begin{array}{c}\text { TRV } \\
(\mathbf{n g} / \boldsymbol{g})\end{array}$ & $\boldsymbol{Q}$ \\
\hline $\begin{array}{c}\text { Songhua } \\
\text { Lake }\end{array}$ & 106.91 & 4000 & 0.03 \\
\hline $\begin{array}{c}\text { Jilin } \\
\text { section }\end{array}$ & 33103.45 & & 6.28 \\
\hline $\begin{array}{c}\text { Songyuan } \\
\text { section }\end{array}$ & 513.4 & 0.13 \\
\hline
\end{tabular}

This paper collected water quality monitoring data in conventional sections of the Second Songhua River (January-July, 2010), water quality parameters as COD, TN and TP were selected as standard pollution index, and the pollution risk index in Songhua river is listed in Table 6.

\section{TABLE VI. THE POLLUTION RISK INDEX}

\begin{tabular}{|c|c|c|c|c|c|}
\hline project & CODcr & $\begin{array}{c}\mathbf{N H}_{3^{-}} \\
\boldsymbol{N}\end{array}$ & $\boldsymbol{P}_{\text {COD }}$ & $\boldsymbol{P}_{\boldsymbol{N}}$ & $\boldsymbol{P}_{\boldsymbol{P}}$ \\
\hline Fengman (Contrast) & 13.25 & 0.298 & 0.88 & 0.60 & 0.225 \\
\hline Qingyuan Bridge & 13.5 & 0.431 & 0.68 & 0.431 & 0.2 \\
\hline Jiuzhan & 13.5 & 0.475 & 0.68 & 0.475 & 0.24 \\
\hline Shaokou & 14.75 & 0.64 & 0.74 & 0.64 & 0.65 \\
\hline $\begin{array}{c}\text { Average for Jilin } \\
\text { section }\end{array}$ & & & 0.70 & 0.515 & 0.36 \\
\hline Animal Farm & 13.3 & 0.723 & 0.67 & 0.73 & 0.74 \\
\hline Xidazuizi & 13.2 & 1.13 & 0.44 & 0.75 & 0.64 \\
\hline Songlin & 12.3 & 0.84 & 0.62 & 0.85 & 0.86 \\
\hline Sancha River & 11.7 & 1.29 & 0.58 & 1.29 & 0.95 \\
\hline $\begin{array}{c}\text { Average of } \\
\text { Songyuan section }\end{array}$ & & & 0.58 & 0.91 & 0.80 \\
\hline \multicolumn{2}{c}{} & & & & \\
\hline
\end{tabular}




\section{RISK MITIGATION MEASURES}

A. Accelerate the implementation of risk prevention work in Jilin area

B. Strengthen the construction of sewage treatment facilities in Songyuan City and surrounding areas, improve the efficiency and coverage of sewage treatment

C. Increase environmental inputs, strengthen the pollution prevention and control

D. Strengthen environmental education and upgrade population quality

\section{CONCLUSION AND SUGGESTION}

According to the research results, the potential ecological risk of water environment in Second Songhua River is mainly because of the release of heavy metals and toxic organic pollutants in sediments of Jilin section and the urban sewage in Songyuan section. In order to solve the problem of ecological risk existed in the Second Songhua River, we should reduce the environmental pressure and the potential ecological risk, accelerate the development of risk prevention work in Jilin section and infrastructure construction in Songyuan City and surrounding areas, improve the rate of domestic sewage centralized treatment, increase the investment in environmental protection, at the same time, combined with the propaganda of environmental protection, strengthen the pollution prevention and supervision.

\section{REFERENCES}

[1] Sun Shijun, Yan Xiaofei, Cui peng et al. A Four-Step Method for Optimising the Normal Water Level of Reservoirs Based on a Mathematical Programming Model-A Case Study for the Songyuan Backwater Dam in Jilin Province, China [J]
International Journal of Environmental Research and Public Health, 2011 (8): 1049-1060.

[2] Johst K, Drechsler M, watozlod F. The application of the Bp neutral network in the estimation of non-point source pollution [J] Procedia Environmental Sciences, 2012, 13: 263-273.

[3] Baojian Liua, Cong-Qiang Liub, Gan Zhanga et al. Chemical weathering under mid- to cool temperate and monsoon-controlled climate: A study on water geochemistry of the Songhuajiang River system, northeast China [J]. Applied Geochemistry, 2013, 31: 265278.

[4] Sun Shijun, Cui peng, Yan Xiaofei et al. Study on the index system for the regional ecological security in Songyuan, Jilin province, China. The International Conference on Environmental Pollution and Public Health (EPPH 2011)

[5] Wan-li Ma, Li-yan Liu, Hong Qi et al. Polycyclic aromatic hydrocarbons in water, sediment and soil of the Songhua River Basin.China. Environmental Monitoring and Assessment, 2013, 7.

[6] W. Ching, M. Mingxia, Q. Wei. Preliminary study on the environmental impact tracking of comprehensive planning in Huaihe River Basin [J]. Human and ecological Risk Assessment, vol. 1, 2005, pp. 16-17.

[7] Landis W G. The frontier in ecological risk assessment at expanding spatial and temporal scales [J]. Human and ecological Risk Assessment, 2003, pp. 89-92.

[8] Wang X.L, Tao S, Dawson R.W, Xu F.L. Characterizing and comparing risks of polycyclic aromatic hydrocarbons in a Tianjin wastewater irrigated area [J]. Environ. Res. 2002, 90: 201-206.

[9] Hunsaker C T, Graham R L, Suter GW II, et al. Assessing ecological risk on a regional scale [J]. Environmental Management. 1990, 98-101.

[10] Barnthouse L W, Suter GW II. Use manual for ecological risk assessment [M]. ORNL, 1988.

[11] L. Jun, H. Da-ju, "Overview on the Indicator and Methods of Environmental Impact Assessment for Planning" [J]. Pollution Control Technology, vol. 19, 2006, pp. 26-27.

[12] Z. Yinglie, G. Ru, "Preliminary study on the impact of the planning environment on tracking and assessment" [J]. Environmental Pollution \& Control, vol. 31, 2009, pp. 84-88.

[13] F. Danchen, Preliminary Environmental Impact Assessment System [J]. Journal of Shanxi Politics and Law Institute for Administrators, vol. 24, 2011, pp. 26-28. 